expectations of new marvels from science have been greatly stimulated; science gives a new promise of material for leaded type and heavy headlines, it may even reach the evening "contents" bill ; camera-men are in waiting at every corner.

It is easy to understand the reluctance, which all this inspires in modest men, to venture on the territory of press publicity, and to incur the risk of inclusion with charlatans whose "amazing" discoveries still find so ready an acceptance there. We believe, however, that the risk is worth while and that with reasonable care the dangers can be avoided. Vigilance is, however, becoming increasingly necessary, and it is of the first importance that public opinion within the scientific world should express itself plainly when this vigilance is neglected.

It is with this sense of obligation that we feel compelled to express very great regret that, in one of the younger universities, the dignity of science should recently have been allowed to undergo what seems to us to be a very serious violation. We shall not attempt to enter into details, nor do we desire to particularise individuals. The essential fact is that a want of vigilance has led to an exhibition of vulgar sensationalism which, as we are well assured by the remonstrances that have reached us, is regarded by the reputable scientific world as being in the highest degree deplorable. We make no attempt to apportion blame; we are concerned only to enter a strong protest. It is possible that what has happened may act as a temptation to a few of the less thoughtful to the empty glories of the limelight. In so far as that is the case, it will, we trust, stir responsible people to the exercise of restraint. We do not think the chief apprehension lies in that direction. We fear rather that what has happened may prove to have given a serious set-back to the efforts, which have recently been showing more success, to induce our men of science to help in a wholesome alliance with the Fourth Estate in what, properly regarded, has the sanctity, and should have the sobriety, of a missionary effort of enlightenment. We can only hope that what has recently happened will leave behind nothing but a salutary warning.

There is at the present time great restlessness in the world ; old landmarks and fixed points, and even rules of life, seem to have disappeared, and we are in the turmoil of readjustments on the grand scale. Amid the grave anxieties of this condition we have a temporary excitement breaking out here and there in all sorts of morbid forms. By coincidence we have in the world of science a corresponding siir of readjustments; let us see to it that we at least are not invaded by the discordant spirit of jazz.

NO. 2869 , vOL. I 14$]$

\section{The Human Factor in Coal Mining.}

$\mathrm{O}$ $\mathrm{N}$ October 2 the Institution of Mining Engineers held its annual meeting, at which Prof. J. S. Haldane was inducted into the presidential chair and gave his presidential address. The occasion was sufficiently unusual to merit special comment. It is not an ordinary occurrence for the president of an engineering institution to be a professor of physiology ; but Prof. Haldane is no ordinary physiologist. He has practically devoted his life to a study of the physiological problems which the miner's occupation presents, and to the discovery of how the miner's health and safety of life and limb are affected by the incidence and accidents of his occupation, and how the ill-effects of these can be guarded against. It is not too much to say that it is to Prof. Haldane's studies that thousands of coal miners in Great Britain owe their lives and health to-day, and that he has played a leading part in the battle against the dangers of the industry which mining engineers are waging with such conspicuous success that coal mining in Great Britain is safer than in any other country in the world.

As might well be expected, Prof. Haldane's presidential address had in it nothing at all technical; it was essentially humanistic and laid stress upon that most important of all factors in any engineering industry, namely, the human element. $\mathrm{He}$ pointed out that one of the most striking characteristics of mining men is the deep and sincere feeling of comradeship that unites all classes amongst those actually engaged in mining work ; or, as he put it: "I have often been present at a colliery during some time of trouble or danger; and it was this comradeship, from highest to lowest, that impressed me most. But whether or not unusual trouble is present, one seems to meet comradeship as one enters the colliery premises or steps into the cage." He points out that it is this readiness with which miners " will give loyal and efficient service, will face any danger, will forgive imagined or real mistakes, and will take the rough with the smooth, the bad times with the good," that makes the miner insist upon his right to be treated as a man and not as a machine ; and Prof. Haldane expresses his strong view that this feeling is really at the bottom of the so-called industrial unrest amongst miners. As he puts it: "Neither high wages, high dividends, nor welfare schemes will satisfy them in this respect, but only discerning and sympathetic treatment, the treatment of comradeship in a common enterprise-such comradeship as existed in and between all ranks during the War, or such comradeship as is taught in the Gospels."

Prof. Haldane makes clear that his experience has taught him that the mining engineer and mine manager, 
unconsciously perhaps, but nevertheless quite sincerely, feel this attitude on the part of their men, and that they fully sympathise with it and endeavour to give it every opportunity for expression within the limits which they find possible, having regard to the safety and wellbeing of the men themselves. In this sense a coal mine " is the outcome of human comradeship, which uses in its own way, and of its own free will, the tools provided by physical and economic knowledge."

Throughout his address, Prof. Haldane shows clearly that he thoroughly appreciates the existence of the feelings of true cordiality, regard, and esteem which employers and employed in the coal-mining industry really entertain for each other, but which as a rule are not evident to those outside the industry, whereas the public at large, seeing only the surface of things, may well be inclined to disbelieve in their existence. Those engaged in the industry know well enough, for example, that during the recent long-drawn-out disputes, colliery owners and managers actually assisted from their funds the strikers of their own pits to tide over that period of hardship, but the general public never hears a word of such kindly actions. Constantly during the recent disputes one heard the opinion expressed by both sides in colliery districts that, if only the busybodies at headquarters would leave them alone, they could settle their own differences readily and amicably.

Prof. Haldane is one of the few who has rightly gauged the feelings of the average colliery manager and coal miner for each other, and he lays stress, as its importance deserves, upon this phase of the relations between masters and men, though he at the same time shows that coal mining must, in the interests of the nation itself, necessarily be so carried on as to be commercially remunerative to all concerned therein, and that the responsibility for seeing that the industry is thus able to pay its way rests primarily on the mining engineer. In Prof. Haldane's own words : "When we realise the actual responsibility to their fellow-countrymen of those whose duty it is to care for the financial soundness of the operations involved in British colliery undertakings, we see at once how great that responsibility is, and how important it is that sufficiently farseeing men should bear it, and should not be suffered to be interfered with by ignorant persons, who are commonly officious in direct proportion to their ignorance."

Prof. Haldane's address is, as we have said, unique in the occasion of its delivery. It is also an outstanding example of the fact, too rarely recognised, that the scientific worker is better able than most men to see the spiritual side of human endeavour, and that no man can be a true physiologist without having at the same time a profound insight into the problems of psychology.

\section{A Veteran's View of Modern Physics.}

Atoms and Rays : an Introduction to Modern Viezes on Atomic Structure and Radiation. By Sir Oliver Lodge. Pp. 208. (London: Ernest Benn, Ltd., I924.) $2 \mathrm{I} s$. net.

$7 \mathrm{HE}$ writing of a popular account of recent advances in any branch of science calls for many qualities if it is to be successful. The author must, in the first place, be able to interest and hold the reader without recourse to sensationalism, a truism which, like many other truisms, is often overlooked. He must be the master of clear and concise English, and remember that many words which have a special and defined significance for the expert have also a general meaning which is much more vague. He must have sufficient critical faculty to be able to select for emphasis the points which are really fundamental, and sufficient adaptability to feel when detail must be sacrificed for the sake of vividness. Above all, he should be able to make the reader see in the researches which he describes an example of the power and beauty of the true scientific method, as contrasted with the inspired guesswork to which the ordinary reader is apt to attribute the advances of science.

Sir Oliver Lodge possesses all these virtues, and, in addition, his own distinguished career as an investigator has left in him.an informed enthusiasm which he is well able to communicate. He is a veteran who sees in the modern campaigns against the unknown a repetition, governed by the same general rules of war, of those earlier ones in which he was a leader, and he speaks with the authority of one who knows the conditions of the conflict, as against those who, having never seen the battle raging, attempt to develop an account of the hostilities from the dry despatches. Nearly twenty years ago he gave us, in his "Electrons," the best general account of the state of the electron theory at that time. Towards the end of that book he mentioned various theories of atomic constitution, and spoke of the "exaggerated uncertainty" of the position with special reference to Sir J. J. Thomson's contention that the atom of hydrogen contained only one electron. He also had something to say of the difficulties in the way of explaining line spectra. To-day he has to tell how the advances of the last fourteen years or so have brought clearness into the subject of the structure of the atom, of the quantum theory, of how Bohr's application of it has gone far to found a reasonable theory of spectra, and, in general, of the present state of the electrical theory of matter and the associated radiation problems. He appeals to a wider audience than he did in the earlier book, for very little general knowledge of physics is now assumed in the reader, NO. 2869 , roL. I I 4 ] 